Татјана Ч. Ђурин ${ }^{*}$

Оригинални научни рад

УДК 821.133.1.09 Рабле Ф.:61

811.133.1'255.2:811.163.41

Примљен: 4. фебруара 2021.

Прихваћен: 21. фебруар 2021.

https://doi.org/10.46630/phm.13.2021.47

Универзитет у Новом Саду

Филозофски факултет

Одсек за романистику

\title{
MORBUS JOCOSUS ET MEDICUS RIDENS : МЕДИЦИНСКА ТЕРМИНОЛОГИЈА У СРПСКОМ ПРЕВОДУ ГАРГАНТУЕ И ПАНТАГРУЕЛА ${ }^{2}$
}

\begin{abstract}
У раду се разматрају улога и значај медицине у књижевном делу Франсоа Раблеа (који је био и лекар) кроз традуктолошку анализу српских преводних еквивалената за Раблеове медицинске термине. Медицина је, како сматра Бахтин, била веома популарна међу хуманистима, а Рабле јој је у свом роману дао сопствени печат кроз бављење венеричним болестима и шаљиву анатомију понекад оличену у готово бесконачним набрајањима делова људског тела, гротескно изобличених, преувеличаних. Имајући у виду Раблеов однос према медицини и људском телу, те Њумаркове и Берманове ставове о превођењу техничких термина, у раду се анализира преводилачки поступак делимичног превода (најчешће промена језичког регистра), којим се служи српски преводилац, Станислав Винавер, са циљем да се провери да ли овај преводилачки поступак, у традуктологији често сматран недовољним, неадекватним, може да у циљном језику и култури оживи Раблеову веселу медицину, његовог и насмејаног лекара, односно да код читаоца из циљне културе изазове смех којем Рабле, и озбиљно, приписује терапеутску улогу.
\end{abstract}

Кључне речи: Рабле, Винавер, медицина, делимичан превод, традуктологија

\section{1. Увод}

Важна улога медицине, људског тела, болести и лекара у роману Франсоа Раблеа (François Rabelais) има своје, бар делимично, објашњење у пишчевој биографији. Напустивши самостан у којем је био калуђер, 1530. године, Рабле започиње студије медицине на универзитету у Мон-

1 djurin.tatjana@ff.uns.ac.rs

2 Рад је проистекао из докторске дисертације Српски превод Раблеовог дела „Гаргантуа и Пантагруел“ из перспективе модерних традуктолошких приступа: етноцентричност, хипертекстуалност, дословност, одбрањене на Филозофском факултету у Новом Саду 2011. године. 
пељеу. Године 1532. одлази у Лион и постаје лекар у лионској болници, али истовремено објављује и критичке списе о учењима античких лека$\mathrm{pa}^{3}$. Године 1537. године, враћа се у Монпеље, завршава студије и стиче титулу доктора медицине. У своје време Рабле је важио за изузетног познаваоца анатомије, и управо је он, у Монпељеу, и извршио прву јавну обдукцију.

Медицинско знање и искуства лекара, стицани током година, нашли су своје место у Гаргантуи и Пантагруелу. Овај значајан аспект Раблеовог дела Михаил Бахтин објашњава свеприсутношћу и популарношћу медицине међу хуманистима који су покушавали да испуне Хипократов захтев и мудрост прожму медицином, а медицину мудрошћу (BAHTIN 1978: 376-377).

Бављење античком медицином, а нарочито учењима Хипократа и Галена, било је, дакле, у XVI веку у моди. Тој моди Рабле није одолео, али је схватању медицине и лечења дао сопствени печат - у лику насмејаног лекара, кроз „веселе болести“ (венеричне, наравно) и шаљиву анатомију оличену у понекад готово бесконачним набрајањима делова људског тела - укратко, кроз смех којем Рабле, и озбиљно, приписује терапеутску улогу⿱中一

Будући лекар, Рабле користи стручне медицинске термине помоћу којих често ствара комични ефекат. Међутим, и друге науке, вештине и уметности (природне науке, јуриспруденција, архитектура, војне вештине, поморство, гастрономија, игре, спорт, нумизматика) представљене су у роману богатом стручном терминологијом коју Рабле прецизно и зналачки користи (BAHTIN 1978: 472).

Управо ово је српском преводиоцу и био проблем, јер му текстови који представљају извор за стару српску медицинску лексику, попут Хиландарског медииинског кодекса или Ходошког зборника, нису били доступни, будући да нису били објављени у време настанка превода Раблеовог романа. Зато је Станислав Винавер, као и Рабле у своје време, био принуђен да се окрене другим изворима лексике: говорном језику, тј. народним називима, старим речима којима је давао нова значења, неологизмима (сопственим кованицама насталим најчешће према већ постојећим моделима у српском језику), дијалектизмима, свему оном усменом, старом, споредном или још нествореном што живи испод књижевног језика, и упоредо са њим.

По сопственом признању, један од највећих проблема Винаверу су задали технички језици и игре речи. Сва његова истраживања и рас3 Јула 1532. објављује Хипократове Афоризме са својим коментарима; крајем 1537. коментарише грчки текст Хипократовог Прогностика; објављује Медииинска писма Ђованија Манардија.

4 Више о улози медицине у Раблеовом делу ANTONIOLI 1976; VILIJAMS 2006. 
питивања везана за поморску, медицинску и ратну српску лексику из XVI века као резултат су давала углавном искварене позајмљенице (из италијанског и немачког) и калкове, те је он, како каже, решење потражио у народним речима: „Прибегао сам народским терминима и гледао сам да будем што разумљивији“ (VINAVER S. 1997: 34). На овом преводилачком поступку Винаверу је својевремено веома замерао Војмир Виња, тврдећи да превођење стручних израза речима из народног језика представља издају изворног текста, пошто Рабле ове изразе користи наменски, да би осликао и разоткрио њихове говорнике: „[...] prevoditi takve situacije turcizmima ili nekakvim nakaradnim i nemogućim krparenjima, znači lišiti piščev stil još jedne važne njegove komponente“ (VINJA 1951: 185).

Гледано из строго филолошке перспективе, Виња је свакако у праву, јер промена језичког регистра представља одступање које, пре свега, утиче на ефекат који текст изазива код читаоца. Традуктолошка анализа, међутим, показује да поступак делимичног превода, којим се Винавер често служи приликом превођења медицинске, али и друге стручне терминологије, не само да не представља издају изворног текста и пишчевог стила, већ управо доприноси да се он боље пренесе у циљни језик и циљну културу5.

\section{2. Анализа корпуса}

Људско тело које се описује у Раблеовом роману углавном је раздвојено на саставне делове, најчешће кости и унутрашње органе који бивају прободени, исечени или поломљени у каквој тучи или бици. Такав је и анатомски приказ смрти Турчина који је на ражњу пекао заробљеног Панургија и кога је „ражањ закачио изнад пупка, крај десне слабине, пробио му џигерицу око трећег криоца, пробуразио пречагу и пробушио срчану опну, па изашао тек негде изнад плећа, између кичменог стуба и леве лопатице“ (RABLE 2000: I, 213)6.

Винаверов превод назива за унутрашње органе је адекватан, али мање прецизан, односно мање стручан од назива у изворном тексту. Le nombril јесте пупак, le flan јесте слабина или бок, и l’omoplate senestre јесте лева лопатица7, али les spondyles су вратни пршљенови, а не кичмени стуб, 5 Више о овој полемици VINAVER S. 1997: 31-35; VINAVER M. 1997: 36-37; ĐURIN 2006.

6 Изворни текст: il luy passa la broche peu au dessus du nombril vers le flan droict, et luy percea la tierce lobe du foye, et le coup haussant luy penetra le diaphragme, et par atravers la capsule du cueur luy sortitla broche par le hault des espaules entre les spondyles et lomoplate senestre (RABLE 1995: 338).

7 У причи о властелину од Башеа чији су сватови пребили ујдурмаша (RABLE 1995: 898), именица omoplates преведена је неадекватно, односно непрецизно, као кључне кости. 
како стоји у преводу. Срчана опна, Винаверов преводни еквивалент за стручни термин (у Раблеово време), la capsule du cueur „перикард, срчана марамица", тачно преноси значење термина, али не преноси и језички регистар изворног текста. Винавер се од медицинске терминологије највише удаљава преводним еквивалентом за la tierce lobe du foye „трећи режањ јетре ", у којем преводилац мења језички регистар, замењујући режањ криоцем, деминутивом и хипокористиком именице крило, а јетру џигерицом, турцизмом који у српском језику превасходно означава јетру животиња (која служи за исхрану) или се пак као ознака за човекову јетру налази у дијалектима српског језика и фраземима (изјести џигерицу некоме, ићи некоме на џигерицу).

Поред делимичног превода, Винавер се при превођењу Рабелове медицинске терминологије служи и преводилачким поступком додавања, као у реченици Les fauciles, comme faucilles, која се налази у епизоди о Белим Покладама, владару острва Испод Жита (RABLE 2000: II, 106-110; RABLE 1995: 968-974)9. Раблеов термин је стручан: fauciles се у његово време односио на латералну кост подлактице (radius) или на латералну кост потколенице (fibula). Желећи да пренесе игру речи, паронимију fauciles - faucilles „српови”, Винавер медицински термин преводи народним називима, жбица и лакатница (ова последња реч није забележена у речницима), а затим „украшава“ ове кости придевима који у први план стављају звучност поређења: Српаста жбица и српаста лакатница као српови.

Осим овога, наш преводилац користи и превод који представља објашњење појма из изворног текста, односно користи себи својствен преводилачки поступак, винаверовску јукстапозицију ${ }^{10}$, као у преводу именице alkatim (варијација у графији: alkatin), што је био назив за пет 8 Античка анатомија јетру је делила на одређени број режњева (RABLE 1995: 338, n. $11)$.

9 Опис Белих Поклада дат је у форми листе, једног од омиљених Раблеових наративних поступака. Листа има синтаксичку структуру $X$ (avoit) comme $Y$, где $X$ представља део тела, а $Y$ ствар са којом се део тела пореди. Делови људског тела се пореде са ни по чему сличним предметима из животне стварности, тако да овако приказана, слика Белих Поклада јесте слика чудовишта са коленима попут шамлица, гузовима попут дрљача, ребрима попут чекрка, рукама попут кукуљача и лобањом попут ловачке торбе. То је слика деформисаног и изопаченог човека исцрпљеног дугим постовима и уздржавањем од свега телесног. Беле Покладе одражавају Раблеов однос према посту и средњовековним предрасудама у медицини против којих се борио. Ипак, Рабле није против поста, већ против претеривања у посту, јер такво претеривање ствара Беле Покладе, џиновско чудовиште чији су полни органи атрофирали (уд му је као папуча, а на његовом телу се налази и Венерин брег, телесна одлика жене, тако да није сасвим сигурно ни ког је пола), флегматично биће које не живи, већ само постоји (LAZAR 1993: 93).

10 О винаверовској јукстапозицији као преводилачком поступку који Винавер систематски користи ĐURIN 2009. 
пршљенова који формирају крсну кост. Уместо стручног термина сакрум (sacrum) или народног назива крста, Винавер се опредељује за чување изворне речи и додаје објашњење: Карличњак-„алкатим“ као трупац.

Овакву слику људског тела, рашчереченог, у деловима, или пак огромног, дебелог, са предимензионираним органима, Михаил Бахтин сматра одликом гротескног реализма:

„Za razliku od kanona novog vremena, groteskno telo nije odvojeno od ostalog sveta, nije zatvoreno, nije završeno, nije gotovo, prerasta samo sebe, izlazi iz svojih granica. Akcenti su na onim delovima tela gde je ono bilo otvoreno za spoljni svet, to jest na otvorima, ispupčenjima, na svakojakim izbočinama i izraslinama: razjapljena usta, ženski polni organi, grudi, falus, debeli stomak, nos. Telo otkriva svoju suštinu, začetak koji raste i izlazi iz svojih granica samo u takvim činovima kao što su oplođenje, bremenitost, porođaj, agonija, jedenje, pijenje, pražnjenje. To je - večno nedovršeno telo koje se stvara i koje stvara, to je - karika u lancu razvitka kroz rađanje, tačnije - dve karike, pokazane tamo gde se spajaju, gde ulaze jedna u drugu“" (BAHTIN 1978: 34-35).

Управо због овога, када је реч о људском телу, скатолошки елементи, сексуални чин, јело и пиће имају тако важну улогу у Раблеовом роману и представљају неке од главних Раблеових тема и стилских поступака, нераздвојивих од приче о дивовима, Гаргантуи и Пантагруелу.

Један унутрашњи орган посебно занима Раблеа и његове јунаке. У жељи да коначно одлучи да ли да се жени, Панургије, између осталих, као свог саветника позива и лекара Точкоњу који женском физиологијом, која утиче на женску психу, објашњава зашто је неминовно да сви мужеви једном постану рогоње. Своје тумачење лекар Точкоња заснива на платоничарској медицини која је сматрала да је материца попут животиње, способна да осећа и реагује независно од саме жене (RABLE 2000: I, 395-397; RABLE 1995: 388). Точкоња даје савете за лечење болести рогова од које Панургије највише страхује (RABLE 2000: I, 390-394; RABLE 1995: 698-704). Превод Точкоњиног говора је већином адекватан и дослован, а адекватно је пренет и високи стил, учени тон лекара, али неке стручне медицинске термине које Рабле користи, Винавер непотпуно или делимично преводи. Придев maleficié је, осим омађијан, како у Винаверовом преводу стоји, значио и импотентан - значење које одговара овом одломку. Именица superfluité означава нешто сувишно, вишак. Не могавши, међутим, да је у контексту ${ }^{11}$ преведе постојећим речима, Винавер ствара нову, незабележену у речницима, излишак, од излишно, али и од излити,

11 Према Аристотеловом учењу, храна пролази кроз три врсте варења: најпре у желуцу, затим у јетри, а онда и у ткивима. Сперма је производ, излучак, коначног варења хране и њеног уграђивања у организам (RABLE 1995: 704, n. 7). 
према већ постојећем (а овде чак и одговарајућем) излучак или исцедак.

Раблеова медицинско-опсцена игра речи у називу (једном од многих) за мушки уд, nerf caverneux, делимично је преведена. Именица nerf jе y XVI веку имала многа значења (живац, сила, снага, главни покретач, жила), и она сва у овом контексту долазе у обзир. Придев caverneux такође се односио на више ствари (пећински, шупљикаст, сунђераст, кавернозан). Не могавши, попут Раблеа, да повеже медицински термин (кавернозан) и опсцену алузију („који улази у пећину“ - уобичајена метафора за женски полни орган), Винавер бира сексуално, шаљивије решење: живац пећински.

Свечани, учени тон Точкоњин док излаже начине за обуздавање чулности, па онда и за спречавање рогова, као и толико пута код Раблеа, одједном постаје поспрдан. Последњи начин за одбрану од болести рогова је сам сексуални чин ${ }^{12}$. Не треба ни рећи да се Панургије опредељује, здушно и радосно, управо за то.

Медицински термини везани за полне органе, које Винавер не преводи одговарајућим српским терминима, налазе се и у опису Белих Поклада. У Раблеово време стручан медицински термин, penilliere „Beнерин брег”, замењен је изведеницом од речи бруца „полна длака”, и у српском преводу гласи бруцара. Термин Венерин брег преводиоцу се вероватно учинио сувише нежним, па стога и неприкладним за опис чудовишта, те је, иако Медицински лексикон предлаже и термин бручик (KOSTIĆ 1981), Винавер створио своју комично-подругљиву реч. Стручни термин за мошње, genitoires, Винавер опет преводи својом кованицом, сполник-окрајак, а такође стручни медицински израз, cremasteres „мишићи затезачи", мишићно ткиво које подиже тестисе (кремастерни рефлекс), преводи описно, као мудни мишићи млекаши, стварајући алитерацију и комични ефекат.

Раблеово занимање за људско тело сасвим природно прати присуство болести и начин њиховог лечења. Тадашњи медицински термини (неологизми, грцизми, латинизми, народни називи) у роману често стоје једни уз друге - учени неологизам и народни назив (épiglotte - gargamelle). Код народних назива за болести Бахтин уочава елементе личног имена или поспрдног надимка, јер су многе болести добијале имена светаца који су сматрани исцелитељима или изазивачима тих болести (le mal saint Antoine, le mal saint Vit) или су једноставно персонификоване, попут сифилиса (La Dame Verolle) и костобоље (La Goutte):

„Imena bolesti imaju ogromnu ulogu u kletvama i proklinjanjima, i često prerastaju u pogrdne nadimke: čas se na čoveka šalju kolera, kuga, zaraza, čas ga i samog nazivaju kolerom, kugom, zarazom. Ovo obeležje lako

12 О семантичком аспекту сексуалног чина и називима за полне органе у француском и српском језику JOVANOVIĆ 2015; JOVANOVIĆ 2016. 
dobijaju i vulgarni nazivi za polne organe. Tako u Rableovoj medicinskoj nomenklaturi ima mnogo imena koja književni govor još nije u dovoljnoj meri uopštio i uglačao da bi mogla postati neutralni nazivi književnog jezika i naučne terminologije" (BAHTIN 1978: 475-476).

Болест од које сигурно највише страхују јунаци Раблеовог романа је гушобоља, стезање и сушење грла, болест за коју постоји само један лек - вино. Таква страшна судбина снашла је и краља Анарха након што је појео специјално слатко које му је послао Пантагруел:

„Али тек што је прогутао прву кашику, гуша се овоме запали, изиђоше пликови по ресици, језик набубри, и шта су знали да му као лек даду, или као неко олакшање, него да пије и опет пије и без престанка пије, јер чим би тргао пехар са усана, језик му је горео. Те тако су му сипали вино право у гушу, на левак“ (RABLE 2000: I, 256) ${ }^{13}$.

Симптоми Анархове болести преведени су адекватно (сви медицински термини су адекватни), али уместо израза sans remission „непрекидно” у којем је присутна алузија на медицински термин remission „повлачење болести, ремисија”, Винавер три пута понавља глагол пити који помоћу прилошких одредби поставља у градацију: да пије и опет пије и без престанка пије. Понављање и градација стварају комични ефекат у опису ове „веселе болести“, а Анархо је излечен онако како се једино његова болест и могла излечити.

Попис најчувенијих и најчешћих болести Раблеове епохе (осим куге) налази се у епизоди о Овејаној Суштини, чији службеници су и лечили ове болести. На овом списку су сифилис, водена болест, грозница, зубобоља, костобоља и туберкулоза, али и болест светог Фрање која не напада тело човека, већ његову кесу - сиромаштво (RABLE 2000: II, 260262; RABLE 1995: 1242-1244). Већи део текста опет представља дослован адекватан превод. У преводним еквивалентима за називе болести, међутим, приметна је промена језичког регистра у неколико случајева. Les hydropiques су они који пате од нагомилавања течности око зглобова и у трбушној дупљи. Стручан медицински термин за ову болест је hydropisie, а у нашој медицинској терминологији томе би одговарао термин хидропс. Винавер преводи народним називом - водена болест. Hetique је био стручан медицински назив за туберкулозу који Винавер опет преводи народним називом - сува болест. Ни називе за три облика туберкулозне грознице Винавер не преводи стручним терминима. Atrophes „који

13 Изворни текст: Mais, tout soubdain qu'il en eut avallé une cueillerée, luy vint tel eschauffement de gorge avecque ulceration de la luette, que la langue luy pela. Et pour remede qu'on luy feist ne trouva allegement quelquonques, sinon de boire sans remission : car incontinent qu'il ostoit le guobelet de la bouche, la langue luy brusloit. Par ce l'on ne faisoit que luy entonner vin en gorge avec un embut (RABLE 1995: 466). 
суши, атрофира" замењен је дотад непостојећом именицом осушница. Tabides „изморен, пропао од умора” постаје преморница, а emaciées „кост и кожа" постаје безмесница - обе такође измишљене речи. Постојећа реч, сушица, овде није употребљена, вероватно због тога што би нарушила ритам набрајања који Винавер ствара измишљеним речима са истим бројем слогова и римом. Остали називи болести у изворном тексту припадају регистру народног говора, а тако су и преведени: verolez су френгичави; fiebvre је грозница; mal des dents је зубобоља; goutte је костобоља. Због недостатка одговарајућих термина у српском језику из превода су испуштене именице tympanistes „који је надувен од воде”, ascites „који пати од водене болести” и hyposargues „који се налази испод меса”. Није јасно, међутим, зашто Винавер реч goutteux не преводи одговарајућим термином костоболни, већ уопштава именицом болесник.

Службеници на двору Овејане Суштине лече ове болести и њихове исцелитељске моћи су веома велике ${ }^{14}$. Све ове болести (укључујући и болест рогова и болест светог Фрање), а нарочито костобоља и сифилис (френга) ${ }^{15}$ у XV и XVI веку сматране су „веселим болестима“, јер су се јављале као последица раскалашног живота, неумереног наслађивања јелом, пићем и сексом. Веселе болести лече се веселим, бурлескним лековима, попут оних на двору Овејане Суштине, а спречавају се веселом профилаксом, попут Точкоњине „Венерине радње“. Оваквом шаљивом схватању болести, онда, приличи и шаљиви исцелитељ, лекар који се смеје, али и лекар коме се смеју.

Лик лекара у Раблеовом делу стоји негде између Хипократовог учења и медицинских шарлатана који су продавали разноразне чудотворне масти. И сам Гаргантуа је у младости, док га је васпитавао учени и мудри Понократ, обилазио апотекаре, мелемаре и траваре, али и пеливане, опсенаре и продавце чудотворних лекова. Говорећи о слици лекара у народној култури средњег века и ренесансе, Бахтин и ту слику види као амбивалентну, јер лекар учествује и у рођењу и у смрти човека (BAHTIN 1978: 195). Бахтин истиче да управо лекар има и највише посла са телом у свим његовим променама (рођење, односно порођај, раст, болести, телесна пражњења, умирање и распадање), тј. са материјално-телесним доле. Високи, хипократовски елемент, и ниски, вашарски и надрилекарски елемент у сложеном и понекад противречном лику лекара Рабле је успео да обједини помоћу свог универзалног и амбивалентног смеха, тако да медицина, односно борба против болести добија елементе фарсе, што 14 Врхунац ове моћи је, свакако, подмлађивање. Наиме, један од исцелитеља „претапа бабе и подмлађује их вештином својом да буду као те цурице“ (RABLE 2000: II, 261).

15 Сифилис се у Европи појавио крајем XV века, тако да је у Раблеово доба био још нова болест. Као и неке друге болести, сифилис је имао и народне називе: maladie de Naples, verole, и вулгарнији: gorre или grand'gorre „бујност, величанственост, раскош”. 
Бахтин сматра карактеристичним за целу Раблеову епоху (BAHTIN 1978: 196).

Негативне стране бављења медицином Пантагруел је увидео још у младости, кад је, обилазећи француске универзитете, стигао у Монпеље, где је желео да „учи за лекара, али му се учини да је тај сталеж превише досадан и мрачан, и да лекари базде на клистир као матори ђаволи“ (RABLE 2000: I, 177).

Пантагруелов однос према медицини и лекарима касније ће се променити, и он ће лекаре, уз теологе и правнике, сврстати међу најважније људе у друштву: „Све што смо и све што имамо састоји се из три ствари: душе, тела и имовине. За одржавање тога постоје данас три врсте људи: теолози за душу, лекари за тело, правозаступници за имовину“ (RABLE 2000: I, 386) ${ }^{16}$. У тој расправи Панургије заступа онај други, вашарски и шарлатански лик лекара: „[...] тело предајемо лекарима, који се сви без разлике ужасавају лекова и никада да метну лек у уста“" (RABLE 2000: I, 386) ${ }^{17}$. Пантагруел заступа хипократовску медицину и брани лекаре: „Другу тачку одобравам, јер видим да добри лекари одређују благовремено сами себи шта треба да чине, ради предохране и чувања здравља, па им и није потребно да се лече помоћу лекова“" (RABLE 2000: I, 386) ${ }^{18}$.

Док је Винаверов превод Панургијевог става према лекарима адекватан и дослован, у преводу Пантагруеловог става уочавају се лексичке модификације, односно избегавање стручних медицинских термина. Стручни термини, придеви prophylactice и conservatrice, замењени су адекватним народним називима, именицама предохрана и чување. У другом делу реченице, Винавер стручне термине therapeutice и curative преводи само једним еквивалентом, глаголом лечити.

Супротстављање озбиљног и вашарског схватања медицине провлачи се кроз цело дело, али чини се да се на крају ипак весела карневалска медицина намеће као доминантна. Врхунац надрилекарства у роману представља чудесно Панургијево васкрсавање Знајше коме је била одсечена глава (RABLE 2000: I, 264; RABLE 1995: 480). Опис чудесног Знајшиног излечења преведен је дословно и адекватно готово у потпуности. Ту где Рабле измишља реч, измишља је и Винавер: назив чудотворног меле-

16 Изворни текст: Tout ce que sommes et qu'avons consiste en trois choses : en l'ame, on corps, ès biens. A la conservation de chascun des trois, respectivement, sont aujourd'huy destinées troys manieres de gens : les Theologiens à l'ame, les Medicins au corps, les Jurisconsultes aux bien (RABLE 1995: 692).

17 Изворни текст: [...] nos corps ès medicins, que tous abhorrent les medicamens, jamais ne prennent medicine (RABLE 1995: 692).

18 Изворни текст: Le second je loue, voyant les bons Medicins donner tel ordre à la partie prophylactice et conservatrice de santé en leur endroict, qu'ilz n'ont besoing de la therapeutice et curative par medicamens (RABLE 1995: 692). 
ма Рабле гради од префикса dia-, уобичајеног у тадашњој апотекарској пракси, и латинизоване именице merdis, од merde „говно”; Винавер „свој“ мелем звучно крсти у прашак враголашак. Друга Винаверова измишљена реч, воскресаљац, од црквенословенског Воскрес, стоји као редунданца за животворни мелем, додатно објашњење у сврхе стварања комике, уместо Раблеовог unguent resuscitatif „оживљавајући мелем”. Изворни израз је благо појачан, а превод још смешнији.

\section{3. Закључак}

Улога медицине у Раблеовом роману, дакле, јесте у великој мери да се прикаже људско тело, односно ренесансна концепција људског тела, концепција коју Бахтин назива гротескном:

„Kroz sav roman teče moćna bujica grotesknog telesnog elementa: telo razuđeno na delove, izdvojeni groteskni organi na primer, creva i utroba, razjapljena usta, žderanje, gutanje, jedenje i pijenje, radnje izlučivanja, mokraća, izmet, smrti, porođaji, mladenaštvo i starost, i t. sl. Tela su pomešana među sobom, sa stvarima [...] i sa svetom. Svuda izbija tendencija ka dvotelesnosti. Svuda je istaknut generički i kosmički momenat tela“ (BAHTIN 1978: 339).

Бахтин сматра да је од свих античких писаца на Раблеову гротескну концепцију тела највећи утицај имао Хипократ, односно Хипократов зборник, у којем су заступљени разни филозофско-медицински погледи на људско тело, болести и лечење, али у којем ипак преовладава гротескна концепција тела која тело приказује као незавршено и отворено, у непрестаној узајамној размени са светом, при чему посебну важност имају излучивање и телесне излучевине (BAHTIN 1978: 372). Управо излучевине организма које су у медицинској дијагностици антике (а и касније) биле тако важне, то тело које излучује, емитује се у свет, у Раблеовом делу створиће, укрштајући се са народном смеховном традицијом, систем комичних скатолошких, гастрономских и еротских слика - једну од основних одлика његове књижевне концепције и стила.

Од Хипократа Рабле највероватније преузима и идеју о вези између медицине и мудрости, и слику лекара-филозофа ${ }^{19}$. Бахтин наглашава да је Раблеова епоха била једина епоха у историји европских идеологија у којој је медицина била у средишту и природних и друштвених наука, тако да су многи велики хуманисти били лекари (Корнелије Агрипа, хемичар Парацелзијус, математичар Кардано, Коперник и др): „Bila je to jedina epoha (pojedinačnih individualnih pokušaja bilo je, naravno, i u

19 Бахтин, чини се, овде заборавља на смех. Раблеов лекар ипак није озбиљни филозоф, већ весели исцелитељ. 
drugim vremenima) koja je svekoliku sliku sveta, svekoliko gledanje na svet nastojala da orijentiše upravo na medicinu“ (BAHTIN 1978: 376).

У Раблеовом роману, међутим, однос према медицини истоветан је односу према свим другим друштвеним и природним феноменима: комичан. Комика произилази из претеривања у невероватном: трудноћа од једанаест месеци, рођење на лево ухо, предимензионирани органи услед преједања мушмулама, свакојака черечења, оживљавања људи са одсеченом главом итд. Раблеове веселе болести, изазване прекомерним уживањем у животу, приказане су такође невероватно, као бенигне, више као непријатности, а не као праве, озбиљне болести, углавном са леталним исходом.

Лекар који овакве болести лечи може бити једино насмејани лекар, medicus ridens, који често користи врло необичне лекове, попут вина, на пример, које се преписује и per os и као дезинфекционо средство (Панургије вином испира Знајшин врат и главу, а затим му даје и да пије). Тај смех лекара и болесника, то је смех и бунтовнички и помирљив, којим се истовремено бори против смрти и мири са смрћу. Трошно људско тело неминовно временом копни, али у том умирању код Раблеа нема ничег тужног: то је весела смрт, иза које долази нови живот.

Винаверов превод делова Раблеовог текста са медицинском тематиком већином је адекватан дослован превод. Остали преводилачки поступци заступљени су у мањој мери. Има појединачних примера етноцентричног превода, супституције, ублажавања и појачавања, додавања и испуштања, превода-објашњења, неологизама. При томе, Винавер је увек вођен жељом да пренесе комични ефекат, било да је тај ефекат створен фонетски и семантички, било алузијама и играма речи. Преводобјашњење преузима улогу преводиочевог паратекста, а омашке су малобројне.

Поступак који је овде најизраженији и који представља најизразитије удаљавање од изворног текста, јесте делимичан превод. Стручне медицинске термине из Раблеове епохе Винавер често преводи њиховим српским паровима који не припадају истом језичком регистру. Многи стручни називи за делове тела, болести и друге медицинске термине у српском тексту имају преводне еквиваленте из народног језика. Овакву промену језичког регистра забрањују поборници дословног превођења, попут Питера Њумарка (Piter Newmark) и Антоана Бермана (Antoine Berman). Њумарк сматра да је то одступање од дословног превода, што је тачно, те да самим тим не може бити дозвољено (NJUMARK 1995: 160). Берман истиче двоструки губитак: брисањем стручних израза нестаје оно суштинско у језику текста, а не долази ни до преношења стручних знања у циљну културу, тако да превод постаје некомуникативан, дво- 
струко издајнички (BERMAN 2004: 72).

Већ је поменуто да је, убрзо након објављивања превода, Винаверу на овом поступку замерио и Војмир Виња:

Posebno mjesto zauzimaju elementi stručnih, tehničkih jezika, kojima se Rabelais služi, kako bi prisilio svoga čitatelja, da ga slijedi i da sebi predoči ono, što mu pisac pripovijeda, jer, iznoseći ma kako nevjerojatne stvari, Rabelais nikada ne napušta preciznost, on vas stalno podržava u uvjerenju o najvećoj ozbiljnosti njegova izlaganja. [...] Tu dolazi u prvom redu medicinski jezik. Rabelais je i sam bio liječnik, i sam se je bavio anatomijom, zanatom zabranjenim svima svećeničkim licima, i na svakom koraku u njegovu djelu nailazimo na anatomske deskripcije, medicinske opise, farmakopejske upute, koje može razumjeti, a prema tome i prevesti samo stručnjak. Svako približno prevođenje toga usko stručnog jezika pomoću nekakvih narodnih ili čak trivijalnih izraza predstavlja uništavanje i deformiranje karakterističnih crta Rabelaisove umjetnosti (VINJA 1951: 185).

Винавер је на ову примедбу узвратио питањем, и дао сопствени одговор: „Како да остварим старинску медицинску терминологију на српском. Покушао сам у духу народског изражавања“ (VINAVER S. 1997: 34). Суочен са тешко решивим проблемом недостатка речи који се често јавља при превођењу старог текста, текста који је од читаоца из циљне културе удаљен неколико векова, Винавер је, дајући предност разумевању текста, ритму и звуку, комици и ефекту, овде морао да се задовољи делимичним преводом, опредељујући се за семантичку адекватност (преводни еквиваленти се односе на исти орган или болест као и речи изворника), на штету стилске - тежак избор за једног преводиоца.

Већина поменутих преводилачких поступака у ствари учествује у поступку компензације, којим српски преводилац надомешта управо старе српске медицинске термине, звучни ефекат или игре речи које су због инкомпатибилности изворног и циљног језика и културе на неким местима морали да буду испуштени. Тако, уместо именице dropace „врста мирисне масти која је служила као лек", а за коју у српском језику постоје преводни еквиваленти, мелем, помада, Винавер ставља своју измишљену реч, длакочуп, сликовитију и смешнију (RABLE 2000: II, 261; RABLE 1995: 1244). Компензацију за на неком другом месту изгубљени звучни ефекат могао би да представља превод придева bistorié, насталог од глагола који значи „правити зарезе ножем или скалпелом (лекарским), урезивати, избраздати, наборати”. Овај придев Винавер преводи речју збагљен (RABLE 2000: II, 110; RABLE 1995: 974), забележеном у Вуковом Рјечнику као глагол збагљати „скупити, наборати, згурити, избраздати” (KARADŽIĆ 1969). На другом месту, опет, не могавши да пренесе двосмисленост именице tortycolly „укоченост врата; лицемер, лажно побо- 
жан човек”, српски преводилац оставља основно значење, изменивши придев, те у преводу стоји укрућен, што код читаоца изазива смех, или бар осмех, због опсцене конотације коју реч може да има (RABLE 2000: I, 264; RABLE 1995: 480).

Све модификације, дакле, (а треба опет нагласити: највећи део текста преведен је адекватно и дословно) увек су у служби комике. Како у преводу целог романа, тако и у области медицине, Винавер успева да пренесе комични тон, било да је он шаљиво-поспрдни, било учено-поспрдни, а комични тон је оно што је у роману увек у првом плану - весели, али разарајући Раблеов смех.

\section{Цитирана титература}

ANTONIOLI 1976: Antonioli, Roland. „Rabelais et la médicine“. Études rabelaisiennes XII, 1976.

BAHTIN 1978: Bahtin, Mihail. Stvaralaštvo Fransoa Rablea i narodna kultura srednjega veka i renesanse. Prev. Ivan Šop i Tihomir Vučković. Beograd: Nolit, 1978.

BERMAN 2004: Berman, Antoan. Prevođenje i slovo ili konačište za dalekog. Beograd: RAD/AAOM, 2004.

ĐURIN 2006: ĐURIN, Tatjana. „Potop od jezika ili krparenje - povodom prvog prevoda celokupnog Rablea“. Godišnjak Filozofskog fakulteta u Novom Sadu, 31 (2006): str. 145-153. [orig.] Ђурин, Татјана. „Потоп од језика или крпарење - поводом првог превода целокупног Раблеа“. Годишњак Филозофског факултета у Новом Саду, 31 (2006): стр.145-153.

ĐURIN 2009: ĐURIN, Tatjana. „Vinaverovska jukstapozicija - poetska prevodiočeva beleška“. Primenjena lingvistika, 10 (2009): str. 311-318. [orig.] Ђурин, Татјана. „Винаверовска јукстапозиција - поетска преводиочева белешка“. Примењена лингвистика, 10 (2009): стр. 311-318.

JOVANOVIĆ 2015: JOVANOVIĆ, Ivan. „De l'aspect morphologique et sémantique du lexique obscène en français et en serbe“. Les études françaises aujourd’hui. Faculté de philologie de l'Université de Belgrade: str. 157-166.

JOVANOVIĆ 2016: JOVANOVIĆ, Ivan. „O semantičkom aspektu seksualnog čina u francuskom i srpskom jeziku. Jezik, književnost, značenje. Filozofski fakultet u Nišu: str. 243-255. [orig.] ЈОВАНОВИЋ, Иван. „О семантичком аспекту сексуалног чина у француском и српском језику“. Језик, књижевност, значење. Филозофски факултет у Нишу: стр. 243-255.

KARADŽIĆ 1969: KARADŽIĆ, Vuk Stefanović. Srpski rječnik. Beograd: Nolit, 1969. [orig.] КАРАЏИЋ, Вук Стефановић. Српски рјечник. Београд: Нолит, 1969.

KOSTIĆ 1981: KOSTIĆ, Aleksandar (ur.). Medicinski leksikon. Beograd, Zagreb: Medicinska knjiga, 1981.

LAZAR 1993: Lazard, Madelaine. Rabelais l'humaniste. Paris: Hachette, 1993.

NJUMARK 1995: Newmark, Peter. A Textbook of Translation. Hemel Hempstead, 
Hertfordshire: Pheonix ELT, 1995.

VILIJAMS 2006: Williams, „Alison. Sick Humour, Healthy Laughter: The Use of Medicine in Rabelaiss Jokes“. The Modern Language Review 101/3 (2006): str. 671-681.

VINAVER M. 1997: VINAVER, Milica. „Polemika o prevodu Rablea“. Almanah Vinaver, 1 (1997): str. 36-37. [orig.] Винавер, Милица. „Полемика о преводу Раблеа“. Алманах Винавер, 1 (1997): стр. 36-37.

VINAVER S. 1997: VINAVER, Stanislav. „Ne sutor ultra crepidam, Povodom kritike na moj prevod Rablea“. Almanah Vinaver, 1 (1997): str. 31-35. [orig.] Винавер, Станислав. „Ne sutor ultra crepidam, Поводом критике на мој превод Раблеа“. Алманах Винавер, 1 (1997): стр. 31-35.

VINJA 1951: Vinja, Vojmir. „O jeziku i stilu Rabelaisovu i o novom prijevodu Gargantue i Pantagruela“. Republika-časopis za književnost i umjetnost, 2 (1951): str. 184-193.

\section{Извори}

RABLE 2000: RABLE, Fransoa. Gargantua i Pantagruel, tom I i II. Prev. Stanislav Vinaver. Beograd: Zavod za udžbenike i nastavna sredstva, 2000. [orig.] РАБЛЕ, Франсоа. Гаргантуа и Пантагруел, том I и II. Прев. Станислав Винавер. Београд: Завод за уџбенике и наставна средства, 2000.

RABLE 1995: Rabelais, François. Euvres complètes. Éd. Guy Demerson. Paris: Seuil, 1995. 
Tatjana Đurin

\section{MORBUS JOCOSUS ET MEDICUS RIDENS: LA TERMINOLOGIE MEDICALE DANS LA TRADUCTION SERBE DE L'OEUVRE DE RABELAIS}

La médecine est l'un des sujets les plus importants dans la vie et dans l'oeuvre littéraire de François Rabelais. En insistant sur les parties inférieures du corps, sur les fonctions de digestion, d'excrétion et de reproduction, c'est-à-dire en présentant un corps grotesque, inachevé, toujours en métamorphose et en interaction avec l'extérieur, Rabelais, médecin éclaire de son temps, lutte contre la magie, la superstition et les pratiques des médecins charlatans. La médecine est pour Rabelais une source inépuisable de lexique, d'idées et d'images: de longues listes de termes anatomiques, des maladies vénériennes, des accouchements terrifiants ou prodigieux, des résurrections et des remèdes miraculeux. La médecine participe dans la création du fameux rire rabelaisien, ce rire auquel Rabelais attribue un rôle thérapeutique. Le comique dans le roman a donc des "vertus médicinales ", de sorte que Rabelais nous présente (et se présente comme) un médicin qui rit et qui fait rire pour soigner les malades (et réconforter ses lecteurs). Dans cet article nous examinons certains équivalents serbes des termes médicaux de Rabelais, surtout ceux qui n’appartiennent pas au même registre de langue et représentent des exemples de l'équivalence partielle. Bien que Stanislav Vinaver traduise de nombreux termes techniques du domaine médical par des termes appartenant au registre familier ou populaire de la langue serbe, l'analyse traductologique montre que le traducteur serbe a réussi à recréer le même effet comique de l'oeuvre originale. Vinaver privilégie la transposition du sens, de la sonorité et du comique et, faisant face à un choix difficile, il opte pour des équivalents sémantiques des termes techniques de Rabelais, en sacrifiant le style.

Mots clés : Rabelais, Vinaver, médecine, équivalence partielle, traductologie 